УДК [347.4:61] (477)

DOI https://doi.org/10.32849/2663-5313/2020.1.06

Олександр Соболев, канд. юрид. наук, доцент кафедри цивільного права та процесу факультету № 6

Харківського начіонального університету внутрішніх справ

\title{
МЕДИЧНІ ФОБІЇ У РАЗІ УКЛАДЕННЯ ДОГОВОРУ ПРО НАДАННЯ МЕДИЧНИХ ПОСЛУГ ТА ЇХ ЮРИДИЧНІ НАСЛІДКИ
}

У статті розглядаються питання врахування медичних фобій у разі укладення договору про надання медичних послуг та їх юридичні наслідки. Звернено увагу, що иивільне законодавство виходить із того, що волевиявлення учасника правочину має бути вільним і відповідати його внутрішній волі. Наведене прямо впливає на формування волі та волевиявлення сторін договору про надання медичних послуг, якими є лікар та пачієнт.

Першорядним є питання про порядок досягнення між лікарем та пащієнтом згоди щодо предмета договору, що, як правило, пов'язано з відсутністю певних медичних знань у пачієнта взагалі $i$ про хворобу, яку необхідно вилікувати, зокрема. Актуалізується відповідна проблематика у контексті: 1) необхідності врахування медичних фобій, які здебільшого притаманні пачієнту, саме під час укладання договору на надання медичних послуг; 2) впливу відповідних фобій на формування волі та волевиявлення пачієнта.

Питання вивчення страху саме на часі для філософії, психології, психотерапї та психіатрії. Підсумовується, що, на жаль, право практично не приділяє увагу вивченню ивого феномена, хоча він може бути підставою для впливу на волю контрагента під час укладення досліджуваного договору. Отже, для правознавства невирішеним свогодн є питання: яким чином фактор страху впливає на укладення договору про надання медичних послуг.

Зроблено висновок, що такі психологічні факти як медичні фобіі, істотно впливають на юридичний факт - процес укладання договору про надання медичних послуг. Перш за все че пов'язано з порушенням загальних вимог до чинності правочину, передбачених ч. $3 \mathrm{~cm} .203$ ЦК України, а саме волевиявлення учасника правочину, яке має бути вільним і відповідати його внутрішній волі. В аспекті розглядуваної проблематики воля особи під впливом зазначених страхів не відповідає вимогам, передбаченим законодавством щодо змісту волі та ї зовнішнього вираження. Доводиться, що юридичним наслідком такої невідповідності є порушення зазначених вимог, додержання яких є необхідним для чинності правочину, $i$, як наслідок, визнання недійсним договору про надання медичних послуг.

Ключові слова: договір про надання медичних послуг, медична фобія, умови договору, лікар, пацієнт, фізична особа.

Постановка проблеми. У період планової економіки, коли у колишньому СРСР існувала державна планова система охорони здоров'я, відносини у сфері надання медичних послуг регулювалися виключно нормами адміністративного права [1, с. 30] Надання таких послуг у сучасних умовах здійснюється на підставі договору, цивільноправова природа якого не викликає сумніву.

У правозастосовній практиці виникають проблемні питання укладення, виконання та розірвання договору про надання медичних послуг. Саме на стадії укладення договору про надання медичних послуг визначаються істотні умови договору, права та обов'язки сторін за договором про надання медичних послуг. Проте на цій стадії укладення договору про надання медич- них послуг досить часто пацієнт перебуває у стані страху щодо медичного втручання, є слабкою стороною цього договору.

Метою статті є з'ясування впливу медичних фобій, які стосуються психологічного стану фізичних осіб, на наслідки укладення договору про надання медичних послуг.

Аналіз останніх досліджень і публікацій. У цивільно-правовій доктрині протягом тривалого часу договір про надання медичних послуг був мало дослідженим. Нині відбулися кардинальні зміни у вивченні проблеми укладення договору про надання медичних послуг. У площині цивільного права відповідний договір вивчали такі вчені, як С. Б. Булеца [2], А. А. Герц [3], Г. О. Сироткіна [4], О. I. Смотров [5] та ін. Однак ще 
існує ряд питань, які вимагають більш конкретного розгляду. Так, наприклад, недостатньо розкрито питання, що стосується процедури укладення договору, щодо відповідності волевиявлення сторін внутрішній волі як однієї з умов дійсності договору про надання медичних послуг.

Виклад основного матеріалу. У теорії цивільного права чітко вказані критерії вираження волі суб'єкта на вчинення правочину. Особа, вчиняючи правочин, має чітко і ясно висловлювати свою волю на встановлення, зміну або припинення цивільних правовідносин. Загальним, найкращим способом вираження волі на вчинення правочину визнається словесний спосіб, коли судження про волю особи робиться не приблизно, а на основі прямо висловленого нею бажання. Цей спосіб краще забезпечує необхідну ясність у правочинах, а отже, і необхідну стабільність цивільних правовідносин [6, с. 216-217]. Природно, обговорення лікаря 3 пацієнтом недуги, якщо така $є$ у останнього, способів і варіантів його лікування та очікуваних результатів спочатку проходить у вербальній формі. I вже у разі досягнення певної згоди на надання медичних послуг договір укладається у формі, передбаченій для даного виду договорів (переважно - проста письмова форма). У цивільному законодавстві загальні вимоги, дотримання яких є необхідним для чинності правочину, відображені у ст. 203 Цивільного кодексу України від 16 січня 2003 р. (далі ЦК України). Що стосується безпосередньо наявності волі та волевиявлення у правочині, то відповідно до ч. 3 ст. 203 ЦК України волевиявлення учасника правочину має бути вільним і відповідати його внутрішній волі. Отже, для виявлення відповідності волевиявлення сторін правочину їхній внутрішній волі, слід визначити сторони договору про надання медичних послуг.

Основи законодавства України про охорону здоров’я від 19 листопада 1992 р. № 2801-XII (далі - Основи законодавства України про охорону здоров'я) у ч. 1 ст. 3 визначають пацієнта як фізичну особу, яка звернулася за медичною допомогою та/або якій надається така допомога. Так, у теорії медичного права пацієнтом визнається особа, яка звернулася за медичною допомогою, отримує медичну допомогу та пов'язані з нею послуги незалежно від того, є чи немає у неї захворювання. За іншим підходом, пацієнтом визнається хворий, який лікується у лікаря, тобто обстежується та лікується у медичному закладі [7, с. 5]. Запропоновано й більш широке поняття пацієнта: пацієнт - це фізична особа, яка звернулася до лікувально-профілактич- ної установи чи фізичної особи - підприємця, що надає медичні послуги, та отримує медичну допомогу - діагностичну, лікувальну чи профілактичну [7, с. 6].

У ч. 1 ст. 34 Основ законодавства України про охорону здоров'я надається визначення лікуючого лікаря, яким визнається лікар закладу охорони здоров'я або лікар, який провадить господарську діяльність 3 медичної практики як фізична особа - підприємець і який надає медичну допомогу пацієнту у період його обстеження та лікування.

3 розглянутого вище виникає цілком закономірне питання про порядок досягнення сторонами згоди щодо предмета договору. Це, як правило, пов'язано з відсутністю певних медичних знань у пацієнта взагалі і про хворобу, яку необхідно вилікувати, зокрема. I, що саме головне, постає питання: як досягти певної згоди поміж пацієнтом та лікарем щодо укладення договору про надання медичних послуг, враховуючи певні фобії, які здебільшого притаманні пацієнту.

Передусім необхідно розглянути сам предмет договору про надання медичних послуг як істотну умову договору.

На думку професора медицини I. Г. Галя, як об'єкт медичної послуги виступає сама людина, вірніше, іiï організм, невід'ємною властивістю якого виступає здоров'я [8, с. 14]. В Основах законодавства України про охорону здоров'я, в абз. 1 ч. 1 ст. 3 , здоров'я визначається як стан повного фізичного, душевного і соціального благополуччя, а не тільки відсутність хвороб або фізичних дефектів. У цивільному законодавстві здоров'я вже розглядається як самостійний об'єкт - особисте немайнове благо (ст. 201 ЦК України).

За твердженням Г. О. Сироткіної, саме вчинення медичних дій, спрямованих на відновлення і підтримку здоров'я, тобто лікування пацієнта, i виникнення прав і обов'язків у зв'язку з наданням медичних послуг спрямоване на укладення договору про надання медичних послуг [4, с. 68-69].

Однак, розглядаючи механізм укладення договору про надання медичних послуг, необхідно звернути особливу увагу на психологічний стан пацієнта, а саме на ті наслідки, які викликає у нього феномен страху. На думку О. О. Комлева, страх як негативна емоція чинить переважно негативний вплив на людину, сковуючи його сили і можливості, притупляючи у ньому почуття власної гідності, позбавляючи ініціативи та прозорливості, паралізуючи волю [9, с. 36].

На думку психологів, страх перед можливими захворюваннями входить до десятки найсильніших страхів. Люди завжди боялися 
хвороб, причому ця боязнь у людини неухильно підвищується з віком. I тільки вже при досягненні похилого віку, коли хвороби стають фактично повсякденною реальністю, страх хвороби перероджується у страх смерті (ця фобія буде детально розглянута нижче O. C.) $[9$, c. 41].

Слід зазначити, що питання вивчення страху саме на часі для філософії, психології, психотерапії та психіатрії. На жаль, право практично не приділяє увагу вивченню цього феномена, хоча він може бути підставою для впливу на волю контрагента під час укладення договору. Отже, виникає питання: яким чином фактор страху впливає на укладення договору про надання медичних послуг.

Серед страхів виділена спеціальна група фобій - медична. До неї входять: алгофобія - боязнь болю; ягемофобія - боязнь крові; дентофобія - боязнь стоматологічного лікування; нозомекофобія - боязнь лікарень; тріпанофобія - боязнь голок; фармакофобія - боязнь лікуватися, приймати ліки; опіофобія - боязнь (страх) лікарів та іншого медичного персоналу, цю фобію іноді також визначають як ятрофобію [10, с. 123]. I як «основа» всіх зазначених вище страхів страх смерті - танатофобія.

Стосовно страху перед хворобами, то виникає він з цілого ряду причин. Це і страх перед шкодою, що наноситься функціям та зовнішньому вигляду людини (ампутація кінцівок), перед можливістю втрати працездатності на тривалий час, а отже, i матеріального стану (пневмонія з ускладненнями), втрати соціального статусу у суспільстві (венеричні захворювання), перед можливістю настання летального результату (інфаркт, інсульт) тощо [9, с. 41].

Природно, що все вищезазначене не може не впливати на волю пацієнта. I, приймаючи те чи інше рішення, він фактично сліпо довіряється рішенням лікаря. Позначення лікарем самої проблеми зі здоров'ям у пацієнта і настання можливих негативних наслідків для нього може дуже близько стикатися 3 психічним тиском на пацієнта. Навіть у разі відмови від лікування він зобов'язаний підписати заяву про те, що є попередженим про негативні наслідки, які можуть для нього наступити, аж до летального результату. Найчастіше це серйозно впливає на психічний стан людини, пригнічує її волю, відповідно, і рішення вона приймає під тиском певних чинників, не завжди відповідних спокійній та зваженій відповіді.

Як приклад необхідно навести такий різновид фобій, як ятрофобія - страх відвідування лікаря. Лікарі називають це «боязнь білого халата». Наслідки цієї фобії різні, насамперед у хворого 3 цією фобією неможливо навіть точно виміряти артеріальний тиск - результат буде спотворений. Як наслідок, діагноз буде поставлений неправильно, що й буде підставою надання неналежної послуги. Як свідчить практика, люди 3 цією фобією вважають, що до відвідин лікаря вони здорові, а після візиту до лікаря у них виявиться цілий ряд хвороб, також для них страшний «вердикт» про наявність у них невиліковного захворювання, наслідки якого пов'язані з летальним результатом. Це і $є$ основною причиною для відтягування відвідування лікаря.

У принципі, пацієнт може боятися і не самого фахівця-медика, а неприємного діагнозу, болючої або ганебної медичної процедури, зараження інфекційним захворюванням. Відповідні негативні емоції пацієнта, як результат, досить часто переносяться на лікарів.

Ятрофобія, по суті, є ірраціональним, нав'язливим страхом. Сама ж боязнь лікарів може бути пов'язана з негативними емоціями, причиною яких прямо або опосередковано став сам лікар. Джерела цих негативних емоцій можуть бути різні. Це і власний досвід невдалого спілкування з лікарем, лікарська помилка, інформація про лікарські помилки, отримана із зовнішніх джерел (публікацій у ЗМІ, оповідань людей, чуток тощо) та інше [10, с. 123$]$.

Найсерйозніший страх, який відчуває пацієнт лікувального закладу, - це страх смерті. Цей страх пов'язаний, перш за все, 3 тим, що, як вважають вчені-філософи, смерть - головне зло людства [11, с. 240]. Як зазначає Г. В. Шор, лякає і приводить у жах вид страждань вмираючих, внаслідок чого розвивається танатофобія, коли смерть помилково ототожнюється 3 тими стражданнями, які заподіює невиліковна хвороба. Медики вважають, що смерть це не мука, а стан полегшення, звільнення. Оскільки смерті передує безпам'ятство, вона безболісна [12, с. 32]. Основна думка Г. В. Шора: смерть - це не миттєвий одноактний процес, а явище тривале. Виходячи з його теоpiї, якщо функція саморегуляції, кореляції i регенерації працює погано, то з'являється хвороба (тимчасове відхилення від норми). На наступній стадії, у стані постійного відхилення, хвороби призводять до інвалідності; і на останній стадії - стійка постійна інвалідність призводить до смерті [13, с. 27]. Це можна подати як ідеальний ланцюжок проходження життєвого циклу, але це спірне судження. Смерть може настати й минаючи всі згадані стадії. 
Як протидія страху смерті - танатофобії - сьогодні все більшого поширення набуває так звана танатотерапія - напрям тілесно орієнтованої психотерапії, який прогресивно розвивається та містить прийоми встановлення (відновлення) контакту людини з різними видами смерті і вмирання. Танатотерапія моделює т. зв. «правильне вмирання», навчає у всьому знаходити взаємозв'язок процесів «життя»- «смерті» [14]. Але, незважаючи на це, страх перед лицем смерті (танатофобія) у більшості пацієнтів існує.

Не завжди і лікар може повноцінно оцінити фактичний стан хворого та можливість настання для нього тих чи інших негативних наслідків. Перестраховуючись, він може озвучити і більш небезпечні наслідки для пацієнта, що також впливає на придушення його волі і прийняття необгрунтованого рішення. На жаль, існує і певна категорія лікарів, які 3 метою наживи «ставлять» пацієнтові більш важкий діагноз, тим самим повністю пригнічуючи його волю. У цьому випадку, відповідно до ст. 231 ЦК України, правочин, вчинений особою проти iï справжньої волі внаслідок застосування до неї фізичного чи психічного тиску з боку другої сторони або з боку іншої особи, визнається судом недійснім. Винна сторона (інша особа), яка застосувала фізичний або психічній тиск до другої сторони, зобов'язана відшкодувати ій збитки у подвійному розмірі та моральну шкоду, що завдані у зв'язку з вчиненням цього правочину.

Аналізуючи вищесказане, можна зробити висновок про те, що у цьому випадку йдеться про вплив певних фобій на психічний стан пацієнта, що зрештою призводить до недійсності договору надання медичних послуг на підставі придушення волі пацієнта. Тобто важливо розглянути питання про можливість застосування норм ЦК України до розглядуваного випадку. Так, правила ст. 225 ЦК України застосовуються до правочинів, які вчинені дієздатною особою, але за обставин, що свідчать про тимчасову наявність у неї такого стану, який призводить до дефектів у формуванні внутрішньої волі та її справжнього волевиявлення. Частина 1 ст. 225 ЦК України визначає умови фактичного стану, які не дозволяють дієздатній фізичній особі адекватно виразити свою волю щодо вчинюваного правочину. До них належать такі: по-перше, коли особа не усвідомлювала значення своїх дій та (або), по-друге, не могла керувати ними. Для визнання правочину таким, що має дефекти волі і волевиявлення, необхідно встановити наявність хоча $б$ однієї з двох зазначених у статті підстав.
До причин стану особи, за якого вона не усвідомлювала значення своїх дій або не могла керувати ними, можна віднести: сильне нервове хвилювання, тимчасовий психічний розлад, травма, больовий шок тощо. Тобто все те, що здебільшого пов'язано 3 наданням медичної послуги. Важливо звернути увагу на те, що самостійне приведення фізичної особи у такий стан не перешкоджає можливому визнанню укладеного нею правочину недійснім [15, с. 384].

Окреслена проблема є досить актуальною для вирішення питань правового забезпечення порядку укладення та виконання договору про надання медичних послуг.

\section{Висновки}

Підводячи підсумки, слід зазначити, що такі психологічні факти, як медичні фобії, істотно впливають на юридичний факт процес укладання договору про надання медичних послуг. Перш за все це пов'язано з порушенням загальних вимог до чинності правочину, передбачених ч. 3 ст. 203 ЦК України, а саме волевиявлення учасника правочину, яке має бути вільним і відповідати його внутрішній волі. В аспекті розглядуваної проблематики воля особи під впливом зазначених страхів не відповідає вимогам, передбаченим законодавством щодо змісту волі та її зовнішнього вираження. Юридичним наслідком такої невідповідності є порушення зазначених вимог, додержання яких $€$ необхідним для чинності правочину, і. як наслідок, визнання договору про надання медичних послуг недійсним.

\section{Список використаних джерел:}

1. Калмыков Ю. Х. Избранное: Труды. Статьи. Выступления / предисловие В. Ф. Яковлева; сост. О. М. Козырь, О. Ю. Шилохвост; Исследовательский центр частного права. Москва : Статут, 1998. $312 \mathrm{c}$.

2. Булеца С. Б. Цивільні правовідносини, що виникають у сфері здійснення медичної діяльності: теоретичні та практичні проблеми : дис. ... докт. юрид. наук: 12.00.03. Одеса, 2016. 437 с.

3. Герц А. А. Договірні зобов'язання у сфері надання медичних послуг : дис. ... канд. юрид. наук: 12.00.03. Львів, 2016. 421 с.

4. Сироткина А. А. Договор оказания медицинских услуг: особенности правового регулирования. Москва : Статут, 2004. 174 с.

5. Смотров О. I. Договір щодо оплатного надання медичних послуг : дис. ... канд. юрид. наук : 12.00 .03 . Харків, 2002. 177 c.

6. Гражданское право Украины : учебник для вузов системы МВД Украины : в 2-х ч. Часть $1 /$ под. ред. проф. А. А. Пушкина, доц. В. М. Самойленко. Харьков : Основа, 1996. 440 с. 
7. Лавриненко О. О., Рогова О. Г., Панасюк С. А. та ін. Коментар медичного законодавства України. Станом на 01.03.2011 р. Київ : «Видавничий дім «Професіонал», 2011. 360 с.

8. Галь И. Г. Обязательства по оказанию медицинских услуг: проблемы теории и практики Российский судья. 2011. № 3. С. 13-17.

9. Комлев А. А. О природе страха смерти: история вопроса и гипотезы. Вестник ТГУ. Вып. 4 (20). 2000. С. 36-41.

10. Щербатых Ю. В. Психология страха: популярная энциклопедия. Москва : Изд-во Эксмо, 2003.512 с. (Серия «Психология общения»).

11. Ильин Е. П. Психология страха. СанктПетербург : Питер, 2017. 352 с.
12. Шенкао М. А. Смерть как социокультурный феномен. Киев : Ника-Центр, Эльга; Москва : Старклайт, 2003. 320 c.

13. Шор Г. В. О смерти человека (Введение в танатологию). Ленинград : Кубуч, 1925. 117 с.

14. Баскаков В. Ю. Танатотерапия: теоретические основы и практическое применение. Москва : Институт Общегуманитарных Исследований, 2007. 176 с.

15. Науково-практичний коментар Цивільного кодексу України : у 2-х т. Т. I. 3-е вид., перероб. і доп. / за ред. О. В. Дзери (кер. авт. кол.), Н. С. Кузнєцової, В. В. Луця. Київ : Юрінком Інтер, 2008. 832 c.

The author of the article has studied the issues of considering medical phobias while concluding $a$ contract on the provision of medical services and their legal consequences. Special attention has been paid to the fact that the civil law proceeds from the fact that the will of the participant of the transaction must be free and should correspond to his or her own will. The foregoing directly influences the formation of the will and declaration of intention of the parties to the agreement on the provision of medical services that are a physician and a patient.

The primary problem is the issue on the procedure for reaching consent between a physician and a patient on the subject matter of the contract, which is usually associated with the patient's lack of some medical knowledge at all, and about the disease to be treated, in particular. The relevant problem is updated in the context of: 1) the need to take into account medical phobias, which are mostly inherent to the patient, precisely during the conclusion of the contract for the provision of medical services; 2) the influence of appropriate phobias on the formation of the will and declaration of intention of the patient.

The issue of studying fear is relevant for philosophy, psychology, psychotherapy and psychiatry. Unfortunately, it has been summarized that the law does not practically pay attention to studying this phenomenon, although it may be a reason for influencing the will of the counterparty while concluding the researched contract. Thus, the issue on how the fear factor influences the conclusion of the contract for the provision of medical services remains unsolved for the jurisprudence.

It has been concluded that such psychological facts as medical phobias significantly influence the legal fact - the process of concluding a contract for the provision of medical services. First of all, this is related to the violation of the general requirements for the validity of the transaction provided in Part 3 of the Art. 203 of the Civil Code of Ukraine, namely the declaration of intention of the participant of the transaction, which should be free and correspond to his internal will. In the context of the considered issue, the will of the person, under the influence of these fears, does not meet the requirements stipulated by the legislation regarding the content of the will and its external expression. It has been argued that the legal consequence of such a discrepancy is the violation of these requirements, the compliance of which is necessary for the validity of the transaction, and as a consequence, the contract for the provision of medical services is invalid.

Key words: medical services contract, medical phobia, contract terms, doctor, patient, individual. 